\title{
Odnowiona pamięć o Andrzeju Niesiołowskim i jego twórczości naukowej w obszarze teorii kształcenia dorosłych
}

\author{
Renewed Memory of Andrzej Niesiołowski and His Work In \\ the Field of the Adult Learning Theory
}

Streszczenie. Okazją do przypomnienia dorobku naukowego Andrzeja Niesiołowskiego (1899-1945) w dziedzinie teorii kształcenia dorosłych stała się książka Dominiki Jagielskiej i Janiny Kostkiewicz pt. Pedagogika humanizmu społecznego Andrzeja Niesiołowskiego (2015). Bohater książki urodził się i wychował w patriotycznej rodzinie w Wielkopolsce. Tam też na Uniwersytecie Poznańskim ukończył studia, gdzie pod wpływem wybitnych profesorów rozbudził swoje zainteresowania naukowe i pasje badawcze. W stosunkowo krótkim czasie napisał 15 książek i ponad 170 artykułów naukowych, popularno-naukowych i publicystycznych z zakresu socjologii, pedagogiki, polityki społecznej, teorii edukacji dorosłych. Zaprezentował się w nich jako przedstawiciel humanizmu społecznego o orientacji personalistycznej. W jego dorobku naukowym z dziedziny teorii edukacji dorosłych wyróżniają się dwie niewątpliwie wybitne książki: Formy i metody pracy oświatowej (1932) i Koła oświatowo-wychowawcze (1939). W pierwszej scharakteryzował dominujące za jego czasów instytucje oświaty pozaszkolnej w Polsce i Europie. W drugiej opisał ruch samokształceniowy (jego genezę, rozwój i metodykę) realizowany w wielu krajach w kołach samokształceniowych i wychowawczych. Treścią jego refleksji nad tak pojętą oświatą dorosłych jest szukanie skutecznych strategii jej rozwoju celem pożądanej przebudowy - za jej pośrednictwem - struktur życia społecznego i gospodarczego naszego kraju.

Słowa kluczowe: humanizm społeczny, oświata pozaszkolna, edukacja dorosłych, instytucje kształcenia dorosłych, ruch samokształceniowy, stowarzyszenie społeczne, koła oświatowo-wychowawcze, personalizm, struktury życia społecznego, zmiana struktur społecznych.

Summary. The book by Dominika Jagielska and Janina Kostkowicz Pedagogika humanizmu społecznego Andrzeja Niesiołowskiego (Pedagogy of social humanism of Andrzej Niesiołowski) (2015) poses a opportunity of reminding oneself of academic work of Andrzej Niesiołowski 
(1899-1945) in the field the theory of adult learning. The hero of the book was born and brought up in a patriotic family in Wielkopolska (Greater Poland, a Polish region). He graduated there, at the university of Poznan, and under the influence of prominent professors he developed his academic interests and passion for research. In a relatively short period of time he has written 15 books and over a 170 academic, popular science, and journalistic articles that cover the fields of sociology, pedagogy, social politics, and the adult learning theory. In his works he has presented himself as a representative of social humanism with personalist orientation. In his academic works in the field of the adult learning theory two prominent books stand out particularly: Formy i metody pracy oświatowej [Forms and methods of education] (1932), and Koła oświatowo-wychowawcze [Educational academic associations] (1939). In the former he characterized the institutions of extracurricular education in Poland and Europe that were the dominant ones during his lifetime. In the latter he described the self study movement (its genesis, development, and methodology) which was conducted in many countries in self study and educational academic associations. The essence of his reflection on education of adults understood in this way is the search for effective strategies of its development in order to desirably convert our country's social and economic structures.

Keywords: extracurricular education, adult education, self study movement, the adult learning theory, Andrzej Niesiołowski.

Pretekstem do przypomnienia dorobku naukowego Andrzeja Niesiołowskiego (1899-1945) w dziedzinie teorii kształcenia dorosłych stała się książka Dominiki Jagielskiej i Janiny Kostkiewicz pt. Pedagogika humanizmu społecznego Andrzeja Niesiołowskiego (2015). Książka ma charakter poważnego i z pasją napisanego studium historyczno-biograficznego ukazującego nie tylko życie, bogatą twórczość wymienionego Bohatera w obszarze socjologii i pedagogiki i działacza społecznego (w szczególności w obszarze instytucji społecznych Kościoła katolickiego), ale także dojrzałego intelektualnie reprezentanta społecznej oraz pedagogicznej myśli katolickiej.

W kręgach andragogów życie i działalność naukowa Andrzeja Niesiołowkiego były wcześniej dość dobrze znane. Stało się tak dzięki dostępności w bibliotekach jego najważniejszych prac z zakresu teorii kształcenia dorosłych, a także opublikowania jego życiorysu (autorstwa Andrzeja Wędzkiego - zięcia A. Niesiołowskiego) w 1978 r. w Polskim Słowniku Biograficznym. Warto zaznaczyć, że do biogramu tego załączony został wykaz ważniejszych prac A. Niesiołowskiego.

Dominika Jagielska i Janina Kostkiewicz, przygotowując książkę o pedagogice humanizmu społecznego Andrzeja Niesiołowskiego, przeanalizowały liczne dokumenty archiwalne m.in. w Archiwum Uniwersytetu Adama Mickiewicza w Poznaniu i archiwum rodziny (córki Anny) A. Niesiołowskie- 
go, odnalazły i przeanalizowały cały jego dorobek naukowy (artykuły naukowe, popularno-naukowe, publicystyczne, maszynopisy prac niepublikowanych, książki i broszury). Przeanalizowały także prace o A. Niesiołowskim pisane przez różnych autorów.

Wymienioną książkę „otwiera” obszerny Wstęp, w którym J. Kostkiewicz zwraca uwagę na niezwykłość i oryginalność twórczości Andrzeja Niesiołowskiego w obszarze pedagogiki humanizmu społecznego. W rozdziale I monografii ta sama autorka ukazała szczegółowo dynamiczne życie i rozległą twórczość (naukową oraz publicystyczną), a także działalność społeczną interesującego ją Bohatera na tle epoki, w której przyszło mu się rozwijać i pracować. Rozdział drugi wymienionej publikacji to rekonstrukcja personalistycznej (katolickiej) teorii wychowania A. Niesiołowskiego dokonana na podstawie szczegółowej analizy jego spuścizny naukowej i publicystycznej. Zdaniem A. Niesiołowskiego każdy człowiek jest zobowiązany do działań na rzecz własnego rozwoju. Jest też zdolny do realizacji tego procesu. Wychowanie zaś winno odrodzić jednostkę w celu służby narodowi. Ma ono - zdaniem A. Niesiołowskiego - rozwijać siły i możliwości twórcze członków narodu, powodować wzrost „mocy” obywateli kraju. W rozdziale trzecim napisanym w podobnym tonie (tj. personalizmu) autorki ukazały koncepcje przebudowy struktur życia społecznego A. Niesiołowskiego. Ma się ona dokonać przez wychowanie człowieka. Odpowiednio zrealizowane wychowanie, zwłaszcza społeczne (według ideologii personalizmu), to dobry sposób na moralne odrodzenie narodu i angażowanie obywateli w dobre zmiany społeczne. Przez edukację i staranne wychowanie oraz samokształtowanie zmierzać się winno w naszym kraju do budowania silnej Polski. Uzupełnieniem i rozszerzeniem książki Dominiki Jagielskiej i Janiny Kostkiewicz jest wykaz dokumentów dotyczących życia i twórczości (w tym i notatek do wykładów w Oflagu w Arnswalde) pisarskiej, bibliografii opublikowanych przez niego prac, a także antologii (wyjątki) wybranych jego prac naukowych, łącznie z recenzją pierwszego wydania (1938) obszernej książki L. Chmara pt. Kierunki i prądy pedagogiki współczesnej. Wypada zaznaczyć, że Ludwik Chmaj w kolejnym wydaniu tej publikacji zadość uczynił uwagom A. Niesiołowskiego (pominięcie kilku osób) uzupełniając wskazane braki.

Wartościowym dopełnieniem książki Dominiki Jagielskiej i Janiny Kostkiewicz są reprodukowane na ostatnich jej stronach Dokumenty z życia i pracy Andrzeja Niesiołowskiego.

Andrzej Niesiołowski pochodził z rodziny o dużych tradycjach patriotycznych. Kultywowano w niej pamięć o Edmundzie Callierze (1833-1893), pułkowniku polskich oddziałów powstańczych z 1863 r., historyku, literacie 
i krajoznawcy. Tradycje te w dużym stopniu pogłębiali w jego środowisku rodzice i stryj Kazimierz (1872-1949) - ksiądz i działacz społeczny (także na niwie oświaty) w wielkopolskim Pleszewie.

Andrzej Niesiołowski urodził się w Ostrowie Wielkopolskim jako syn miejscowego księgarza (ojciec odbył wiele bibliotekarskich staży zagranicznych, w tym także we Lwowie u Zuzanny z Eberów). Kształcił się w miejscowym gimnazjum, uczestnicząc równocześnie w działalności tajnych organizacji patriotycznych młodzieży polskiej (Towarzystwo Tomasza Zana, harcerstwo). Jako uczeń, w listopadzie 1918 r., wziął udział w wypadkach w swoim mieście związanych z przejęciem władzy z rąk niemieckich, a po tym jako ochotnik walczył w Powstaniu Wielkopolskim (batalion powstańczy sformowany w Szczypiornie). Po demobilizacji, latem 1919 r. zdał - jako ekstern - maturę. Zasadnicze studia (historia i socjologia) odbył (1921-1925) na Uniwersytecie Poznańskim, będąc równocześnie aktywnym członkiem wychowawczego ruchu Elsów. Jego nauczycielami byli wybitni profesorowie, z reguły twórcy rozległych dyscyplin naukowych, m.in.: Kazimierz Tymieniecki (historia), Florian Znaniecki (socjologia), Michał Sobeski (filozofia) Stefan Blachowski (psychologia), Bogdan Nawroczyński (pedagogika). W 1926 r. Andrzej Niesiołowski uzyskał na Uniwersytecie Poznańskim doktorat $\mathrm{z}$ filozofii (na podstawie rozprawy pt. Zagadnienie wolności woli), a w dwa lata później - po zdaniu serii trudnych egzaminów państwowych -dyplom nauczyciela szkół średnich w zakresie historii i socjologii.

Bezpośrednio po magisterium podjął pracę $\mathrm{w}$ poznańskich szkołach średnich. Wdrożył się także w działalność redakcyjną na terenie tamtejszych tygodników („Robotnik”, „Nowy Kurier”). W roku akademickim 1929/30 zlecono mu przeprowadzenie na Uniwersytecie Poznańskim wykładów i ćwiczeń z zakresu teorii oświaty dorosłych. Jak się okazało, były to jedne z pierwszych wykładów tego typu w naszym kraju. P r z eło m o w y m okresem w rozwoju naukowym A. Niesiołowskiego jako teoretyka oświaty dorosłych był r. 1930. Otrzymawszy stypendium Funduszu Kultury Narodowej, przemierzył Szwecję, Danię, Niemcy, Belgię, Szwajcarię, Włochy i Austrię, gdzie poznał działalność ponad 90 stowarzyszeń i instytucji kształcenia dorosłych (nazywanego w latach międzywojennych „oświatą pozaszkolną"). Zebrany w czasie tej wędrówki ogromny materiał stał się podstawą do dopracowania programu wspomnianych wykładów i ćwiczeń na Uniwersytecie Poznańskim oraz inspiracją do pomnożenia pisarstwa naukowego i publicystycznego na temat kształcenia dorosłych. O treści „poprawionych” wykładów (za rok 1930/31) wnioskować można z książki Formy i metody pracy oświatowej. Próba klasyfikacji i analizy socjologicznej wydanej (1932) nakła- 
dem Polskiej Macierzy Szkolnej w Warszawie z przedmową prof. Ludwika Jaxy-Bykowskiego - wtedy dziekana Wydziału Humanistycznego Uniwersytetu Poznańskiego. To za jego akceptacją zorganizowano na Uniwersytecie Poznańskim pierwsze wykłady z teorii oświaty dorosłych, a w 1937 r. powołano do istnienia Studium Oświaty Pozaszkolnej (Stopińska-Pająk, 1994, s. 80). Środowisko naukowe stworzone przez Floriana Znanieckiego, z którym był mocno związany A. Niesiołowski, sprzyjało rozwojowi refleksji nad kształceniem dorosłych, co też aktywizowało twórczo Andrzeja Niesiołowskiego.

Mając spory dorobek naukowy i publicystyczny, Andrzej Niesiołowski w 1938 r. przeniósł się (być może z powodu braku wsparcia przez F. Znanieckiego przy próbie habilitacji) (Jagielska, Kostkiewicz, 2015, s. 29-31) do (działającego od 1928 r.) Oddziału Wolnej Wszechnicy Polskiej do Łodzi (Baranowski, 1977, s. 117). Wykładał tam - w środowisku wcześniej radykalnie lewicowym - pedagogikę (katolicką) oraz kontynuował intensywnie twórczość naukową i działalność społeczną (m.in. w placówkach rozwijanej wtedy w naszym kraju Akcji Katolickiej). Znakiem tej pierwszej jest opublikowanie w 1939 r., nakładem Drukarni i Księgarni Św. Wojciecha w Poznaniu, obszernej (476 s.) monografii pt. Koła oświatowo-wychowawcze. Zadania-teoria-wskazówki praktyczne.

Latem 1939 r. A. Niesiołowski został (jako porucznik rezerwy) zmobilizowany do Armii Poznań. Brał udział w kampanii wrześniowej i w wyniku bitwy nad Bzurą dostał się do niewoli niemieckiej. Przebywał w kilku obozach (oflagach) jenieckich, gdzie angażował się m.in. do pracy oświatowej z jeńcami, jednocześnie kontynuując intensywnie pracę naukową. Wyniki tej pracy w postaci rękopisów (10 rozpraw o łącznej liczbie 2333 stron) zaginęły (Jagielska, Kostkiewicz, 2015, s. 48). Zmarł w oflagu w Dossel 9 lutego 1945 r. $\mathrm{z}$ powodu nieleczonego zapalenia płuc.

W wymienionej publikacji autorstwa Dominiki Jagielskiej i Janiny Kostkiewicz została zamieszczona obszerna, zdaje się już kompletna, bibliografia dorobku pisarskiego, a także rękopisów i maszynopisów A. Niesiołowskiego. Dowiadujemy się z niej, że opublikował on 15 książek i broszur oraz ponad 170 artykułów naukowych, popularno-naukowych i publicystycznych. Są to prace z zakresu: socjologii, pedagogiki społecznej, teorii pracy kulturalno-wychowawczej, pedagogiki kultury.

Artykuły najczęściej publikował w najważniejszych pismach społecznych i oświatowych i kulturalnych lat międzywojennych, tj. w „Przewodniku Społecznym”, „Przeglądzie Katolickim” (często artykuły o poziomie moralnym życia politycznego), „Ruchu Charytatywnym”, „Przeglądzie Powszech- 


\section{8 | Tadeusz Aleksander}

nym”, „Kulturze”, „Tygodniku Literackim, Artystycznym i Społecznym”, „Kulturze i Wychowaniu”, „Oświacie Polskiej”, „Przeglądzie Oświatowym” „Ruchu Katolickim”, „Verbum”, „Okólniku Filareckim” i w in. Kilkanaście jego artykułów zostało wydrukowanych w pracach zbiorowych, księgach pamiątkowych i sprawozdaniach z imprez (np. zjazdów) naukowych i in.

Treść większości tych publikacji stawia Andrzeja Niesiołowskiego w rzędzie najbardziej zdeklarowanych personalistów w pedagogice polskiej lat międzywojennych. Treścią jego pedagogiki personalistycznej jest zaduma nad osobą ludzką i jej naturą, podkreślanie wartości, złożoności, niepowtarzalności osoby ludzkiej, jej praw w postaci godności i wolności, a także potencjalności. Interpretując świat według filozofii personalizmu, uznawał, ze człowiek żyjący w tym świecie tworzy określone wspólnoty i instytucje, by godnie żyć oraz uczciwie i skutecznie działać. Takie same funkcje przypisywał tworzonym przez ludzi instytucjom oświatowo-wychowawczym.

W swojej przy naukowej nawiązywał do takich współczesnych uczonych polskich, jak: Helena Orsza-Radlińska, Florian Znaniecki, Józef Chałasiński, Ludwik Chmaj, Marian Wachowski, Władysław Wolert i in. Odważnie występował też $\mathrm{w}$ roli recenzenta niektórych ich prac, publikując recenzje w pismach naukowych: Józefa Chałasińskiego - Wychowanie w domu obcym (1929), Mariana Wachowskiego - Podstawowe pojęcia oświaty robotniczej (1934), Floriana Znanieckiego - Ludzie teraźniejsi a cywilizacja przyszłości (1935), Ludwika Chmaja - Kierunki i prądy pedagogiki współczesnej (1939).

Współczesnych andragogów zainteresować mogą głównie dwie najważniejsze prace naukowe Andrzeja Niesiołowskiego: Formy i metody pracy oświatowej. Próba klasyfikacji i analizy socjologicznej (1932) oraz Koła oświatowo-wychowawcze. Zadania - teoria - wskazania praktyczne (1939). U genezy obu tkwiło przekonanie o potrzebie i możliwości podniesienia poziomy etycznego i zmotywowanie społeczeństwa polskiego do działań na rzecz rozwoju społecznego oraz gospodarczego własnego kraju, a tym samym poprawy egzystencji i warunków bytowych ludzi żyjących w warunkach niepodległości, okupionej ogromnym poświeceniem jego pokolenia.

Jako personalista-pragmatyk, znający doskonale cechy psychofizyczne oraz potencjał intelektualny i moralny Polaków w odbudowanym kraju, a także świadom ceny odzyskania niepodległości, widział sposób na osiągnięcie tego celu (tj. rozwoju społecznego i gospodarczego kraju) w rozbudowie intensywnej oświaty pozaszkolnej oraz tworzeniu społeczeństwa wychowującego (a właściwie to samokształcącego i samowychowującego) przez zagęszczanie sieci kół oświatowo-wychowawczych. Teorii i metodyce osiąga- 
nia tych celów poświecił obie pracowicie przygotowane (publikowane w częściach nieco wcześniej na łamach czasopism społeczno-oświatowych) książki.

W pierwszej z tych książek autor zwraca uwagę na rosnącą rolę współczesnej mu oświaty pozaszkolnej charakteryzującej się z powodu dynamiki „[...] nieprzejrzanem mnóstwem form [...]” i na duże możliwości kształcenia się człowieka dorosłego. Przyjmując za kryterium relacje między „[...] prowadzącym akcję [...]", tj. nauczającym a uczącymi się, wyróżnia (s. 8-9) trzy typy działań oświatowych. Pierwszy cechuje się oddzielnością nauczających i uczących się. Nazywa te formy „opieką kształtującą”. Druga grupa form charakteryzuje się połączeniem pracy tych dwu elementów i zespoleniem w jednej osobie funkcji nauczającego i uczącego się. Tę grupę form, realizowanych głównie w stowarzyszeniach i zespołach, nazywa „ruchem samokształtowania” (samokształcenia). Grupę trzecią tworzą formy - jego zdaniem - cechujące się brakiem wymienionych elementów. Ich funkcją jest jedynie dostarczanie „[...] materiałów oświatowych i środków pomocniczych [...]” typu wydawnictwa, biblioteki, muzea, czytelnie. Nazwał ją „organizacją środków pomocniczych". Dokonał też wewnętrznej klasyfikacji form zajęć w ramach każdej z tych grup. Formy zaliczone do grupy „opieka kształtująca" podzielił na mniejsze według (poziomu) stopnia intensywności pracy uczestnika. Liczne formy edukacji tego rodzaju podzielił na 3 mniejsze grupy (s. 10): pierwsze to internatowe zakłady oświatowo-wychowawcze w postaci uniwersytetów ludowych i szkół dla dorosłych. Cechą ich jest to, że wychowanek jest pod pełnym, całodniowym oddziaływaniem wychowawczym i w związku z tym musi sporo energii poświęcić pracy nad sobą „[...] nad zdobyciem wiedzy i wyrobieniem własnem [...]”. Drugą część „opieki kształtującej” stanowią „ośrodki oświatowe różnych typów”. Autor zaliczył do tej grupy takie zajęcia, w przypadku których nauczający dorosłych edukuje członków jakiejś już (wcześniej) powstałej grupy społecznej (np. wyznaniowej) lub też grupy specjalnie („celowej”) stworzonej dla celów edukacyjnych, albo i też złożonej z innych chętnych do nauki jednostek (za opłatą lub bez). Łatwo dzisiaj zauważyć, że chodzi tutaj głównie o uczelnie wszechnicowe dla dorosłych typu uniwersytetu powszechnego, niedzielnego, kursy potrzeb własnych i osobistych zainteresowań, tzw. wykłady powszechne i in. Wreszcie trzecia kategoria „opieki kształtującej” to formy tzw. oświaty wewnętrznej, czyli dla grup i środowisk „zamkniętych”: związków zawodowych, stowarzyszeń, zakładów przemysłowych, partii politycznych, grup wyznaniowych $\mathrm{i}$ in.

Natomiast w obrębie ruchu samokształtowania Andrzej Niesiołowski wyróżnił dwie grupy form - pierwsza to kółka i zespoły samokształcenia 
z zadaniami intelektualnymi (a więc głównie „kształcenia”), druga to stowarzyszenia ideowe nastawione na realizację - jako idei głównej - innych celów, np. politycznych, społecznych, gospodarczych i temu podporządkowujące pracę oświatową, kulturalną, sportową, rozrywkową oraz in. Z reguły ich kierownicy w działalności oświatowej preferują zadania wychowawcze. Grupy te mogą podlegać dalszej klasyfikacji ze względu np. na: płeć lub wiek uczestników, realizowany cel, strategię działania i in. W kompleksie tzw. „środków pomocniczych” omawiany Autor wymienia: czytelnictwo, naukę korespondencyjną, muzea i wystawy, przeźrocza i filmy, radio, świetlicę, a nawet organizację wczasów.

Lektura obu wymienionych książek Andrzeja Niesiołowskiego, zarówno Form i metod pracy oświatowej jak i Kót oświatowo-wychowawczych dowodzi ogromnych trudności, jakie pokonywał ich autor przy klasyfikowaniu interesujących go form kształcenia dorosłych. Trudności te wynikały z kilku przyczyn. Pierwsza to brak jakichkolwiek wcześniejszych klasyfikacji i przykładów, do których mógłby nawiązać lub z których skorzystać opracowując swoją klasyfikację. Druga to wielka różnorodność - programowa, organizacyjna i metodyczna - form kształcenia poznanych w Polsce i w odwiedzanych przez niego krajach. Ona to sprawiała, że niektóre formy „nie dawały" się klarownie zakwalifikować do wyróżnionych grup. Oba te elementy są przyczyną umowności i nawet pewnej nietrafności jego klasyfikacji.

W książce pierwszej (Formy i metody pracy oświatowej) (1932), po omówieniu zadań pracy oświatowej i uporaniu się z klasyfikacją jej form, Andrzej Niesiołowski scharakteryzował rozwój w Europie i w Polsce form „kształtujących", począwszy od (internatowych) uniwersytetów ludowych: Dania, Norwegia. Szwecja, Finlandia, Niemcy, Szwajcaria, Austria i Polska (w 1931 r. czynne były cztery: Dalki i Odolanów, Szyce i Dornfeld) i „szkół organizacyjnych" (często kościelnych) przyuczających (przysposabiających) - w różnych krajach - lokalnych działaczy społecznych. Następnie scharakteryzował ośrodki oświatowo-wychowawcze różnych typów. Były to w pierwszym rzędzie: uczelnie wszechnicowe takie, jak uniwersytet powszechny (miasto) czy niedzielny (wieś), w których praca sprowadzała się do „[...] kontaktu krótkotrwałego w określonych periodach i w charakterze czysto rzeczowym w przeciwieństwie do mniej lub więcej osobistego w internatowych zakładach [...]” (s. 107-108). W końcu ukazał formy „oświaty wewnętrznej" (s. 191) przeznaczonej dla określonych grup społecznych typu: stronnictwo polityczne, związek zawodowy, przedsiębiorstwo przemysłowe. Celem tej ostatniej jest kształcenie uczestników według ideału, do którego zdąża dana grupa. Z bogactwa informacji na temat rozwoju i specyfiki róż- 
nych form kształcenia dorosłych w poszczególnych krajach Europy zamieszczonego w tej części omawianej książki czytelnika polskiego zainteresować może opis (s. 59) pracy katolickiego uniwersytetu ludowego (Grenzlanvokshochschule) w Nysie (nazwa niemiecka: Neisse). Była to instytucja koedukacyjna wychowująca młodzież wiejską wszystkich „stanów”. Wśród słuchaczy byli także uczestnicy graniczni.

W części drugiej omawianej książki pt. Ruch oświatowo-wychowawczy (s. 212-239) Andrzej Niesiołowski ukazał rozwój i aktualny stan ruchu samokształceniowego w Polsce i znanych mu krajach, realizowanego w kołach utworzonych głównie w celach edukacyjnych. Istotą tego ruchu była praca samokształceniowa członków rozmaitych (co do pochodzenia i ideologicznej przynależności) kół nad własnym rozwojem intelektualnym i moralnym.

Ruchowi samokształceniowemu realizowanemu w kołach oświatowo-wychowawczych poświęcił Andrzej Niesiołowski drugą obszerną (s. 476) książkę pt. Koła oświatowo-wychowawcze. Zadania - teoria - wskazania praktyczne (1939). Powstała ona z materiału rozległych studiów nad literaturą polską z zakresu socjologii edukacji, teorii oświaty dorosłych, psychologii uczenia się, teorii opieki społecznej. Z jej treści wnioskować łatwo o niemal pełnym wykorzystaniu przy pisaniu dorobku naukowego w dziedzinie teorii kształcenia dorosłych: F. Znanieckiego, H. Radlińskiej, W. Okińskiego, M. Wachowskiego, K. Sośnickiego, F. Popławskiego i in. Przygotowując pracę, A. Niesiołowski przestudiował też stosowne prace w językach: angielskim, niemieckim, francuskim, szwedzkim. Sięgał przy jej pisaniu również do materiału obserwacji wyniesionego ze wspomnianej już podróży zagranicznej, a także własnych doświadczeń edukacyjnych.

Książka ta ma charakter podręcznika metodyki pracy kół oświatowowychowawczych, bardzo mocno osadzonego w teorii pracy oświatowej i wychowawczej (pojęcie i istota, formy organizacyjne, funkcje społeczne). Jest równocześnie rozprawą o ruchu samokształceniowym realizowanym w kołach oświatowo-wychowawczych. A. Niesiołowski traktuje w niej pracę tych kół jako ważny system wychowawczy rozwijający siły umysłowe i moralne uczestników, a przez to mogący skutecznie przełamać bierność intelektualną i wolicjonalną Polaków jego czasów, pobudzić u nich spontaniczność i entuzjazm do społecznego działania, a także przygotować ich do określonej działalności (s. 344). W przekonaniu o potrzebie i możliwości doskonalenia osobowości umysłowej i moralnej w szukaniu optymalnych metod tego doskonalenia wyraża się optymizm pedagogiczny, patriotyzm, a zarazem i personalizm A. Niesiołowskiego. 
Już w obszernym Wstępie do Kół oświatowo-wychowawczych A. Niesiołowski wskazuje na potrzebę poszukiwania nowych „wzorów” w oświacie pozaszkolnej, bo dotychczasowa ekstensywna jej postać reprezentowana przez np. uniwersytet powszechny (w mieście) czy uniwersytet niedzielny (na wsi) już nie wystarcza. Szansę taką stwarzają - jego zdaniem - koła oświatowo-wychowawcze (s. 13-14). To dopiero one rozwijają intensywnie osobowość wychowanków (intelektualną i moralną) w atmosferze „[...] przyjacielskiej i „klimacie” moralnym i intelektualnym [...]”. W rozdziale I książki A. Niesiołowski dokonuje przeglądu koncepcji koła oświatowo-wychowawczego jako formy intensywnego kształcenia dorosłych i ukazuje tradycje tych kół w kilku krajach europejskich (Francji, Belgii, Szwecji, Anglii i Polsce). Rozdziały następne książki to już bardzo rozwinięte rozważania teoretyczne na temat istoty samokształcenia w kołach oświatowo-wychowawczych oraz wskazówki metodyczne na temat: możliwości wychowania i zadań pracy w kołach, rodzaju i formy organizacyjnej kół, doboru i osobowości członków, zasad sprawowania kierownictwa i przodownictwa w kole, procedury zakładania i struktury koła, układania programu pracy i kryteriów jego opracowywania oraz in. Rozdział ostatni (dziewiąty) podręcznika to trafny merytorycznie i szczegółowy „wykład” na temat metod pracy oraz organizacji zajęć w kole.

Tak skonstruowana książka jest „kopalnią” wiedzy na temat teorii i praktyki działalności edukacyjnej kół oświatowo-wychowawczych, dobrze odzwierciedlającą intensywny, pod koniec lat międzywojennych, rozwój tego ruchu, wspieranego przez kilka poradni samokształceniowych (stowarzyszeń oświatowych). Zawarte w niej propozycje metodyczne i organizacyjne mogą również dzisiaj skutecznie wspierać organizatorów ruchu samokształceniowego w stowarzyszeniach.

Trzeba przyznać, że lektura omówionych książek A. Niesiołowskiego nie należy do łatwych. Zdawał sobie z tego sprawę sam autor wyjaśniając, że są to prace dla osób o dość wysokim poziomie wyrobienia umysłowego. Owa trudność tkwi w zwartości (dużo konkretów) treści, sporej liczby terminów, nierzadko nie do końca zdefiniowanych lub definiowanych „wstępnie”, sporej ilości przypisów, dużej liczby nazwisk oraz nazw często mało znanych (niejednemu czytelnikowi) procesów i zjawisk. Dzisiejszemu czytelnikowi ich recepcję utrudnia już niekiedy archaiczne słownictwo, zawiłość językowa niektórych wywodów, a także częste przytaczanie i wtrącenia w wywody autora poglądów oraz teorii innych osób piszących na ten sam temat.

Wartość naukową i dydaktyczną obu omówionych książek „podnoszą” załączone do nich obszerne bibliografie prac polskich i zagranicznych, dobrze informujące o poziomie refleksji naukowej i praktyki w interesujących 
A. Niesiołowskiego obszarach naukowej penetracji. Nadto książka pierwsza (Formy i metody pracy oświatowej) ubogacona została o skorowidz nazwisk i skorowidz rzeczowy zawierający nazwy charakteryzowanych organizacji i wykaz omówionych w niej zagadnień.

Zastanawiające dzisiaj jest jak to się stało, że mimo takiego dorobku naukowego A. Niesiołowski po II wojnie światowej popadł, na wiele lat, w naukowe „zapomnienie”. Nie pisano o nim i nie polecano do czytania jego prac. Nie wspomina o nim nawet tak wytrawna autorka, jak Helena Radlińska w Oświacie dorosłych wydanej wprawdzie w 1947 r., ale powstałej w znacznej części z artykułów pisanych pod koniec lat międzywojennych, a więc w okresie szczytowej aktywności twórczej A. Niesiołowskiego i jego współpracy z Wolną Wszechnicą Polską - Oddział w Łodzi. A książka H. Radlińskiej zaopatrzona jest w obszerną bibliografię oraz szczegółowe skorowidze: rzeczowy i nazwisk. Helena Radlińska pomija to nazwisko także w obszernej (s. 552) i starannie przygotowanej książce $Z$ dziejów pracy społecznej i oświatowej ubogaconej nie tylko o rozległy aneks zawierający indeksy: osobowy i problemowy instytucji, stowarzyszeń krajowych, czasopism i wydawnictw ciągłych. Nie wymienia jego nazwiska nawet w aneksie nr 12 pt: Straty (s. 500-509), gdzie zamieszcza biogramy ludzi straconych i zmarłych w czasie okupacji niemieckiej z obszaru polityki społecznej i służby społecznej oraz oświaty pozaszkolnej. Jest tam np. biogram Władysława Okińskiego, kolegi A. Niesiołowskiego i wychowanka F. Znanieckiego.

W świetle tego faktu trudno uwierzyć, by H. Radlińska nie znała tragicznych losów A. Niesiołowskiego. Być może sygnalizowane pominięcie jego Osoby spowodowane zostało różnicami w poglądach na te same zjawiska oświatowe (H. Radlińska w czasie okupacji opracowała książkę Samokształcenie wydaną trzykrotnie jako druk konspiracyjny). W czasach powojennych o dorobku naukowym A. Niesiołowskiego informował Kazimierz Wojciechowski w sporządzonej przez siebie Bibliografii oświaty dorostych.

Do dorobku naukowego A. Niesiołowskiego nawiązał dopiero po wojnie Franciszek Urbańczyk. Opracowując swoją Dydaktykę dorostych, opisał w niej pracę kół oświatowych jako jeden z sześciu systemów dydaktycznych, czerpiąc szeroko z dorobku naukowego A. Niesiołowskiego, zwłaszcza z podręcznika Koła oświatowo-wychowawcze. Zadania - teoria - wskazania praktyczne.

W nowej polskiej rzeczywistości politycznej (lat 90. XX w.) twórczość Andrzeja Niesiołowskiego w obszarze teorii kształcenia dorosłych przypomniała Agnieszka Stopińska-Pająk, nawiązując do niej w starannie opracowanej Andragogice w Drugiej Rzeczypospolitej oraz wymieniając główne jego 
prace w załączonej do Andragogiki obszernej bibliografii. Agnieszka Stopińska-Pająk opracowała też sporej wielkości biogram Andrzeja Niesiołowskiego (wymieniając także - w porządku chronologicznym - ważniejsze jego prace), publikując go w Słowniku pedagogów polskich. Nie doczekał się natomiast A. Niesiołowski podobnego uwidocznienia w (stale powiększanym i uzupełnianym) Słowniku pedagogicznym autorstwa Wincentego Okonia.

W warunkach tej stopniowo przypominanej, ale nadal niepełnej wiedzy o pracowitym życiu i rozległej działalności naukowej A. Niesiołowskiego z radością powitać należy książkę wymienionych krakowskich autorek: Dominiki Jagielskiej i Janiny Kostkiewicz Pedagogika humanizmu społecznego Andrzeja Niesiołowskiego. Jest ona odkrywczym wykładem wiedzy o bogatym życiu oraz rozległej twórczości naukowej i publicystycznej tego Autora, niepospolitego patrioty i twórcy głębokiej humanistycznej koncepcji wychowania narodowego (w duchu personalistycznym), swoimi propozycjami celnie trafiającego $\mathrm{w}$ potrzeby edukacyjne i wychowawcze współczesnego mu pokolenia Polaków, żyjących $\mathrm{w}$ warunkach $\mathrm{z}$ trudem odbudowanego oraz intensywnie rozwijanego państwa.

\section{Bibliografia}

Jagielska D., Kostkiewicz J. (2015), Pedagogika humanizmu społecznego Andrzeja Niesiołowskiego, Wydawnictwo Uniwersytetu Jagiellońskiego, Kraków.

Niesiołowski A. (1932), Formy i metody pracy oświatowej. Próba klasyfikacji i analizy socjologicznej, Nakładem „Księgarni Polskiej” Towarzystwa Polskiej Macierzy Szkolnej, Warszawa.

Niesiołowski A. (1939), Koła oświatowo-wychowawcze. Zadania - teoria - wskazania praktyczne, Księgarnia Św. Wojciecha, Poznań.

Stopińska-Pająk A. (1994), Andragogika w Drugiej Rzeczypospolitej, Wydawnictwo Uniwersytetu Śląskiego, Katowice.

Stopińska-Pająk A. (1998), hasło: A. Niesiołowski, [w:] W. Bobrowska-Nowak i D. Drynda (red.), Stownik pedagogów polskich, Wydawnictwo Uniwersytetu Śląskiego, Katowice, s. 152-153.

Wędzki A. (1978), hasło: A. Niesiołowski, [w:] Polski Słownik Biograficzny, t. XXIII, Zakład Narodowy im. Ossolińskich, Wrocław, s. 52-53. 